\title{
Optimalizací inkluze k prohlubování nerovností ve vzdělávání
}

\section{Denisa Denglerová, Radim Šíp}

Celý vzdělávací systém v současné době balancuje na hraně strmého srázu. Tak jako v dalších oblastech našeho života i ve školství zjevuje pandemická krize problémy, které zde dlouhodobě bublají pod povrchem. Počínaje vysokým průměrným věkem učitelů a jejich nižšími IT kompetencemi přes př́liš obsáhlé kurikulum zaměrené na faktografické znalosti až po normativní způsob hodnocení žáků. Výrazným problémem českého školství zůstává také nerovnost šancí a príistupu ke kvalitnímu vzdělávání. Výsledky ve vzdělávání jsou u nás silně podmíněny celkovým socioekonomickým statutem rodiny, z níž dítě pochází. Daniel Prokop považuje za hlavní důvod této nerovnosti velmi rozdilnou kvalitu škol. Škola, kterou žáci navštěvují, rozhoduje až o $44 \%$ jejich úspěšnosti (Prokop, 2019) Na základě různých výzkumných šetření se v tomto roce odhaduje, že z povinného vzdělávání vypadlo cca 10-15\% žáků (PAQ Research, 2021). Snízit tyto nerovnosti bylo jedním z principů/ cílů inkluzivního či společného vzdělávání. Jaký je jeho současný stav?

V dubnu 2015 byla prijata novela, která zakotvila školní inkluzi v našem právním systému. $\mathrm{V}$ parlamentu prošla zcela hladce, zákon podepsal prezident. Konečně vznikla stabilní institucionální a finanční infrastruktura, o kterou se školy po létech prázdných slibů mohly opríít. Již v záŕí téhož roku se však objevily první snahy inkluzi omezit. Přitom mnozí z kritiků jen půl roku předtím zvedli pro novelu ruku. Klíčovou otázkou tedy je, jak je možné, že MŠMT okamžitě po odchodu Kateřiny Valachové z postu ministryně začalo mluvit o „optimalizaci“ inkluze? Copak MŠMT neví, že aby získalo relevantní data na prípadnou optimalizaci, musí vyčkat nějaký čas? Nesvědčí to o tom, že MŠMT fakticky nemá źádnou dlouhodobou strategii inkluze? Odpověd' na tyto otázky je zarážející a prostá - a samozřejmě smutná.

Toto téma jsme analyzovali hlouběji v jiném textu (Denglerová at al., 2021). V něm prèkkládáme podrobně popsané zjištění: Rychlé a bezproblémové přijetí inkluzivní novely školského zákona bylo dáno mezinárodním tlakem Rady Evropy a Evropské komise. Tyto instituce chtěly dořešit kauzu „D. $\mathrm{H}$. a ostatní vs. ČR", v níž Evropský soud pro lidská práva rozhodl v neprospěch ČR. V této kauze šlo o zmařené studijní dráhy osmnácti romských dětí, které byly podle rozhodnutí Evropského soudu pro lidská práva neoprávněně zařazeny do speciálního vzdělávání. Soud mimo jiné zjistil, že tato skutečnost se netýká pouze těchto 18 stě̌̌ovatelů, ale že se jedná o systémovou záležitost. Proto ve svém rozsudku z roku 2007 nařídil ČR celkovou nápravu této situace. Ještě $\mathrm{v}$ roce 2014 tato 
náprava nebyla uspokojivě provedena. Rada Evropy požádala o pomoc Evropskou komisi. Ta $s$ ČR v té době vyjednávala Dohodu o partnerství a podmínila čerpání peněz $\mathrm{z}$ fondů EU nápravou této situace.

Náhle bylo nutné předložit Evropské komisi nějaké řešení. Díky tomu byly podpořeny inkluzivní koncepty, které již předtím vznikaly paralelně na úřadu vlády pro legislativu a na dalších odborech různých ministerstev - např. v Agentuře pro sociální začleňování. Štěstí přálo připraveným. Tak vznikl velmi rychle vcelku moderní koncept pojetí inkluze, který ČR nabídla EU s tím, že se v rámci tohoto systémového pojetí vyřeší také problematika Romů. (Zde jen podotkněme, že se dodnes situace Romů významně nezlepšila - Kohout Diaz at al., 2018.) EU toto řešení prìjala. Protože se jednalo o velké peníze, které měly být $\mathrm{z}$ evropských fondů čerpány (cca 900 miliard Kč), celá politická scéna se shodla na novele zákona. Bez komplikací novelu prrijala, rozhodla dokonce o rychlé implementaci legislativy (již od záŕí 2016), a novelu podepsal prezident Zeman.

To vše ale bez hlubší politické rozpravy, a tedy také bez toho, aby politici pochopili, že se nejedná jen o nějakou „trendy záležitost“, ale o klíčovou změnu, která významně promění efektivitu školství a je zároveň velkou investicí do budoucnosti ČR. A tak jakmile byly podmínky splněny, čerpání peněz zahájeno a mezinárodní tlak ustal, začala být tato novela okamžitě torpédována. Jedním z prvních byl prezident Zeman, který začal mluvit o školství jako o koloně, která se pohybuje rychlostí nejpomalejšího vozidla. Další a další se $\mathrm{k}$ němu přidávali. $Z$ veškerého dění je zřejmé, že velká část politické reprezentace je k inkluzi, kterou sama svými hlasy podpořila, hostilní. Navíc tím také dává najevo, že hlavnímu cíli inkluze ve školství vůbec nerozumí.

Vzhledem $\mathrm{k}$ tomu, že diskuse o smyslu, efektivitě a dopadu inkluze neproběhla mezi politickými představiteli, nebyla reflektována ani na celospolečenské úrovni. Inkluze ve školství je dodnes veřejností vnímána jako kontroverzní téma, kterému navíc rozumí každý (každý přece chodil do školy). Přitom není možné mít inkluzivní školství, aniž by idea inkluze nerezonovala i v dalších oblastech společnosti. Inkluzivní legislativa, kterou školy začaly postupně chápat, oceňovat a využívat ve prospěch žáků se speciálními vzdělávacími potřebami (SVP), je velmi křehká a ohrožená záležitost.

Od konce roku 2015 „optimalizačni“ snahy sillí. Přesuňme se do současnosti. V zárí 2020 byla bez odborné diskuse předložena vyhláška o vzdělávání žáků se speciálními vzdělávacími potřebami a žáků nadaných. Navrhovaná vyhláška výrazně redukovala především podpůrná opatření pedagogické intervence a asistenta pedagoga. Chtěla mimo jiné zúžit nárok na podporu v podobě přidělení asistenta žákủm podle préedem stanovených diagnóz. Těmi podpořenými zůstávali zejména žáci s diagnózami mentálního postižení nebo poruch chování. O podporu by ale prišsli napríiklad žáci s tělesným postižením či žáci ze sociálně znevýhodněného prostředí. Následkem zárijové vyhlášky by se počet asistentů pedagoga ve školách zredukoval až o dvě třetiny současného stavu. Bez potřebných podpůrných opatření by se ocitlo více než 10000 školou povinných dětí (Denglerová \& Šíp, 2020).

Návrh vyhlášky vzbudil tak mimořádnou vlnu nespokojenosti $\mathrm{v}$ rámci mezirezortního 
rízení ministerstev, $\mathrm{v}$ odborných organizacích i na platformách rodičů, že náměstek ministra Kolár na jednání školského výboru přislíbil stažení a přepracování vyhlášky. MŠMT ovšem přepracovalo vyhlášku podivným a netransparentním způsobem. Odborná diskuse se opět nevedla. Vznesené príipomínky nikdo neřešil a 31. 12. 2020 vyšla vyhláška č. 606/2020 $\mathrm{Sb}$. ve sbírce zákonů s nabytím účinnosti od 1. 1. 2021. Takový spěch je v době pandemie nejen nepochopitelný, ale především podežrelý!

MŠMT stále nezveřejňuje data, ze kterých vychází, ani nepředkládá odůvodnění, jak $s$ daty analyticky pracuje. Výzkumná pedagogická pracoviště, odborná veřejnost ani profesní organizace tak nemají možnost kontroly jeho práce. Jejich vlastní data však ukazují, že postup ministerstva je přinejmenším pochybný. Je skutečně inkluze tak drahá? A v porovnání s čím? Skutečně je problém $\mathrm{v}$ asistentech pedagoga či v pedagogické intervenci? Jaká data pro to ministerstvo má? Zatím jsme slyšeli pouze odkazy na šetření České školní inspekce, ale výklad současného stavu, kterou tato instituce poskytuje, je významně odlišný od toho, co předkládá MŠMT. Jaká ještě další významná data má ministerstvo k dispozici a proč je nesdílí s odbornou veřejností? Ovšem ty nejzásadnější otázky zní: Nedestruuje MŠMT základní princip přijaté inkluzivní legislativy, když do stavby založené na adresné podpoře konkrétních žáků zavádí ad hoc výjimky, pravidla a nesmyslné škrty? A pokud ano, co to vypovídá o MŠMT?

Poslední dvě otázky jsou klíčové. Shrňme si hlavní dopady nedávno přijaté vyhlášky $\mathrm{v}$ celém jejím kontextu:

1. Počet asistentu pedagoga sice MŠMT nakonec prímo neredukovalo, ale $\mathrm{v}$ rozpočtu zůstal škrt 800 milionů (S rušením..., 2020), nebo dokonce 1,2 miliardy (Lauder, 2021) na jejich platy. Tento škrt se původně vztahoval $\mathrm{k}$ dnes již neaktuální verzi vyhlášky, nicméně zůstal v platnosti, přestože asistenti nebudou redukováni. Rozpočet ministerstva je tedy v této kapitole významně zkrácen, ale protože musí vyplatit školám peníze na priznané asistenty, jinak by jeho chování bylo protiústavní, bude muset tyto peníze „najit“ někde jinde. Nejenže ministerstvo nevytvořilo podporu školám, které $s$ asistenty ještě neumí pracovat, ale navíc se snažilo na základě nerelevantních argumentů počet asistentů snízit. Teprve na nátlak veřejnosti, která zjistila, jak velké počty asistentů a žákủ by redukce zasáhla, ustoupilo ze svého záměru, nechává však v rozpočtu díru, kterou bude muset nesystémově zalátat. A na to opět doplatí školy, učitelé a žáci. Přesně takové nelogické kroky svědčí o tom, že ve vztahu k inkluzi MŠMT nemá propracovanou strategii. A právě to vede $\mathrm{k}$ dalšímu rozevírání nůžek mezi školami, které dokážou kvalitně pracovat se žáky s SVP, a těmi školami, které nikoli. Nerovnost vzdělávacích šancí v závislosti na tom, zda dítě chodí do školy prvního či druhého typu, se bude stále prohlubovat.

2. Vyhláškou se na druhou stranu prímo upravuje rozhodnutí, za jakých podmínek bude potřebným žákům poskytnuta pedagogická intervence. Připomeňme, že podpůrné opatření od druhého stupně výše je ze zákona nárokově hrazeno státem. Ještě před čtyřmi měsíci mohla pedagogická intervence spadat do všech pěti stupňů podpory podle toho, jak náročné je s daným žákem pracovat, a školy od druhého stupně podpůrného opatření výše měly ze zákona dostat na pedagogickou intervenci peníze z MŠMT. Ministerstvo však jedinou nově prìidanou větou $(\$ 4 \mathrm{a}$ odst. 3 vyhl. 
č. 606/2020 Sb.) převedlo veškerou pedagogickou intervenci do prvního, nenárokového stupně. Proto o zařazení dítěte do tohoto typu pomoci může rozhodovat škola, $\mathrm{v}$ konečném důsledku její ředitel. S tím jsou ale spojeny velké systémové změny ve financování. Málokdo si všiml té skutečnosti, že došlo k tichému přesunu peněz, který je možná na hraně ústavnosti. Peníze, které z původní kapitoly ze zákona muselo MŠMT školám vyplácet za přiznanou intervenci, byly částečně převedeny do kapitoly na nadtarifní složky platu. Provedenou pedagogickou intervenci nyní mají ředitelé proplácet učitelům $\mathrm{z}$ těchto peněz. Jenže právě tuto kapitolu bude MŠMT moci podle své potřeby bez omezeni škrtat. To znamená, že se tímto „chytrým“ krokem zbavilo své zákonné povinnosti proplácet přiznanou pedagogickou intervenci na žáka. Aniž si to mnozí ředitelé uvědomují, MŠMT je vehnalo do velmi nepř́íjemné situace. Ředitelé sice nemají povinnost přiměřené odměny za doučování vyplácet, ale pokud tak činit nebudou, utrpí celý proces intervencí. Pokud soudní ředitelé odměny vyplácet budou, budou se muset strachovat, že jim paušál nevystačí, případně budou muset snižovat odměny za intervenci. A samozřejmě se budou muset modlit, aby nedošlo ke škrtům v nadtarifní složce, $\mathrm{k}$ čemuž jistě dojde.

Existuje zde skutečně dobrý důvod, proč by o potřebnosti pedagogické intervence měly rozhodovat jednotlivé školy, respektive jejich ředitelé na základě doporučení školního poradenského pracoviště. $\mathrm{Za}$ této situace totiž škola nebude muset čekat několik měsíců na doporučení z pedagogicko-psychologické poradny a žáka do pedagogické intervence bude moci zařadit okamžitě, jak tato potřeba vyvstane. Má to ale jeden háček. Nepřiprave- nost našeho školského systému. Kdyby byl natolik robustní v rovných vzdělávacích šancích pro všechny žáky jako např. ve Finsku, byl by přesun zodpovědnosti na jednotlivé školy krokem správným směrem. Avšak za současné podoby našeho systému toto rozhodnutí jen opětovně systémově podpoří narůstání odlišností mezi jednotlivými školami. Školy s osvíceným managementem využijí vyhlášku ve prospěch žáků s SVP, nicméně školy, v nichž je management neustálými změnami vyčerpaný a trpí regulérně syndromem vyhoření, se pravděpodobně uchýlí $\mathrm{k}$ jednodušší variantě a opatření pedagogické intervence budou poskytovat co nejnižšímu počtu dětí. Můžeme se jenom dohadovat, kterých škol je $\mathrm{v}$ našem systému více. $\mathrm{V}$ každém případě se nerovnost vzdělávacích šancí dále prohlubuje!

Dostáváme se tedy $\mathrm{k}$ jádru, $\mathrm{k}$ paradoxu implementace inkluze. Idea společného vzdělávání měla přispívat $\mathrm{k}$ redukci nerovnosti vzdělávacích šancí. $\mathrm{V}$ tomto parametru patříme $\mathrm{k}$ jedněm $\mathrm{z}$ nejhorších $\mathrm{v}$ Evropě. To bylo jednou z hlavních motivací zavedení inkluze, která mimo jiné přinesla narovnání finanční nespravedlnosti. Ty školy, jež se naučily efektivně pracovat s žáky s SVP, mohou být konečně podpořeny poměrně $\mathrm{k}$ tomu, $s$ kolika žáky skutečně pracují. Dříve se stávalo, že peníze, které nutně na tuto "nadstandardní “ péči potřebovaly, musely generovat ze svých rozpočtů, př́padně saturovat ochotou učitelů pracovat nad rámec svých povinností. To bylo však dlouhodobě neudržitelné. Právě přijetí inkluzivní legislativy tuto strukturální nespravedlnost odstranilo. Ovšem nekoncepční a nesystematické zásahy MŠMT, jež navíc nestojí na relevantních datech, naopak přispějí $\mathrm{k}$ tomu, že nerovnost se bude zvyšovat. MŠMT tak vytvárí prostředí, 
které systémově generuje možnost zhoršeni rovné podpory žáki se speciálnimi vzdělávacími potrebami. Stát opèt rezignoval na roli garanta spravedlivé distribuce financí a nezodpovědně přenáší zodpovědnost zpět na školy, které jsou ale v celém systému nejzranitelnější.

Co tedy skutečně MŠMT získává tímto jednáním? Získává jediné! Bude moci na vládě raportovat: „Ušetřili jsme v kapitole inkluze“. To velkou část vlády i politické reprezentace potěší. Ve své podstatě však slova MŠMT o ušetřených financích znamenají toto: „Podařilo se nám narušit hlavní princip inkluze - adresnost financování. Systém bude pomalu erodovat. Postupně bude narůstat počet selhávajících žáků a těm nakonec nezbyde nic jiného, než se vrátit do škol praktických a speciálních. Návrat do starých dobrých časů rozvírajících se nůžek nerovných vzdělávacích šancí je zajišstěn!" Protože předpokládáme, že na MŠMT sedí soudní lidé, obáváme se, že zde ve skutečnosti nejde o peníze. Pokud o peníze přece jenom jde, pak je tato politika projevem naprostého diletantství.

\section{Literatura}

Denglerová, D., \& Šíp, R. (2020, 22. záŕí). Zmèna vyhläšky boř́ koncept inkluze na školách. (Online). Dostupné z www.em.muni.cz/komentare

Denglerová, D., Kalenda, J., Sedláková, M., \& Šíp, R. (2021). Dancing between money and ideas: Inclusion in primary education in the Czech Republic between 2005 to 2020. International Journal of Inclusive Education (v recenzním řízení).

Kohout Diaz, M., Bittnerova, D., \& Levinska, M. (2018). Limity inkluze ve vzdělávání romských dětí v České republice: boj o identitu žáka. Pedagogická orientace, 28(2), 235-268.

Lauder, S. (2021, 5. ledna). Změny v inkluzi: Asistenti nakonec zůstali, ale zhorší se systém doučování. Respekt, 5. 1. 2021.

PAQ Research (2021). Život během pandemie. (Online). Dostupné z https://idea.cerge-ei.cz/paq-zivot-behem-pandemie

Prokop, D. (2019). Slepéskurny. O chudobè, vzdèlávání, populismu a dalšich výzvách českéspolečnosti. Brno: Host. S rušením... (2020, 10. prosince). S rušenim mist asistentů pedagogů nakonec ministerstvo nepočitá. Zmèna proběhne v doučování. (Online). Dostupné z https://www.irozhlas.cz/zpravy-domov/asistent-pedagoga-skola-ministerstvo-skolstvi_2012101659_ada

Vyhláška č. 606/2020 Sb., kterou se mění vyhláška č. 27/2016 Sb., o vzdèláváni žáki se speciálními vzdělávacimi potrébami a žáků nadaných, ve znění pozdějších prèedpisů

PhDr. Denisa Denglerová, Ph.D.

Masarykova univerzita, Pedagogická fakulta, Katedra sociálni pedagogiky;

e-mail: denglerova@ped.muni.cz

doc. Mgr. Radim Šip, Ph.D.

Univerzita Tomáše Bati, Fakulta humanitnich studii, Centrum výzkumu, a Masarykova univerzita, Pedagogická fakulta, Katedra sociálni pedagogiky; e-mail: sip@utb.cz 